\title{
Fish landings in Barcelos, in the Middle Negro River Region, Amazonas
}

\author{
S. O. Inomata \& C. E. C. Freitas \\ Institute of Agricultural Sciences, Federal University of Amazonas, Brazil
}

\begin{abstract}
The purpose of this study was to gather information about fish landings in Barcelos, in the Middle Rio Negro region. Data were collected from fishing boats at weekends and from stalls where fish were processed and sold during the week. The results showed that in the period from February 2012 to January 2013, 56.0 tons of fish were landed and that average landings were $3.6 \pm 2.2$ tons/month and $1.1 \pm 0.7$ tons/month for fishing boats and for small boats with outboard motors, respectively. Pacu (subfamily Myleinae), aracu (family Anastomidae) and tucunare (Cichla spp.) were the main species caught and accounted for approximately $50 \%$ of the landings. The Demeni River, Lake Anauali and Zamula streamlet were the most exploited fishing areas. Fishing boats exploited the lakes in the dry and flood seasons and the rivers in all seasons of the hydrological cycle, with a slight predominance in the falling-water season. Streamlets were also exploited by fishing boats in all the seasons apart from the flood season. Lakes were the preferred environment for small boats with outboard motors in the dry season. While rivers were exploited by these boats throughout the year, streamlets were exploited mainly in the rising- and fallingwater seasons. There was a decrease in fishing effort in the flood season and an increase in the dry season. Average CPUE was 21.9 and $23.9 \mathrm{~kg} /$ fisherman/day for fishing boats and for small boats with outboard motors, respectively. Keywords: exploited species, Negro River, fishing effort.
\end{abstract}

\section{Introduction}

Fishing is a traditional activity in the Amazon and has many unusual characteristics compared with fishing in other regions of Brazil, including the variety of species exploited, the amount of fish caught and the dependence of riverside communities on it as a source of income and protein [1]. 
The Negro River provides a small proportion of the fish supply to major urban centers in the region, and it has been estimated that only $4.3 \%$ of the fish landed in Manaus comes from this river [2]. This figure is expected to decrease as a result of State Decree 22.304 dated November $20^{\text {th }}, 2001$, which limited commercial fishing in the Negro River basin to that needed to supply communities and towns along the stretch of river extending from the mouth of the Branco River to the border with Venezuela and Colombia.

However, fishing on the Middle Negro River is one of the main economic activities of the local population, who depend on it directly or indirectly for survival [3] as it provides an important part of their income and is also their main source of protein. In addition to subsistence and commercial fishing, leisure fishing and fishing for ornamental fish are also practiced in the region.

For a long time most of the wealth generated in Barcelos came from the exploitation of ornamental fish, which accounted for over $60 \%$ of the population's income. However, because of the decline in this activity in recent years as a result of competition with other regions of the Amazon and the contraction of the international market, many fishermen have migrated to commercial fishing and, more recently, leisure fishing [4].

Monitoring of fish landings and fishing effort is essential to gain an understanding of the extent to which stocks are being exploited and to support decisions related to fishery management [5]. Nevertheless, existing statistics on fish landings relate to the Solimões-Amazonas channel, and little is known about commercial fishing in blackwater rivers. This study, which is one of the first on fish landings in the Middle Negro River, therefore sought to gather information on fishing activity in the municipality of Barcelos by estimating the volume of fish landed and identifying the most important species, the environments in which fish were caught and the variation in fishing effort.

\section{Materials and methods}

\subsection{Study area}

The study covered the Middle Negro River region and focused on the municipality of Barcelos in the northwest of the state of Amazonas (Figure 1). The municipality covers an area of $122,475.73 \mathrm{~km}^{2}$, making it the largest municipality in the state by area. It is located on the right bank of the Middle Negro River at a distance of $396 \mathrm{~km}$ in a straight line or $496 \mathrm{~km}$ by river from the state capital Manaus.

The Negro River basin is known for its high diversity of fish species, as well as its low stock biomass for individual species compared with whitewater rivers [6]. Some 950 species have been described, many of which are endemic. Notable among these is cardinal tetra (Paracheirodon axelrodi), which has been extensively exploited as ornamental fish and accounts for $80 \%$ of the volume of fish exported annually [7]. Barcelos is currently a popular destination for recreational fishing, and the region is estimated to receive some eight thousand tourists during the fishing season, which lasts throughout the low-water season, from September to March. 

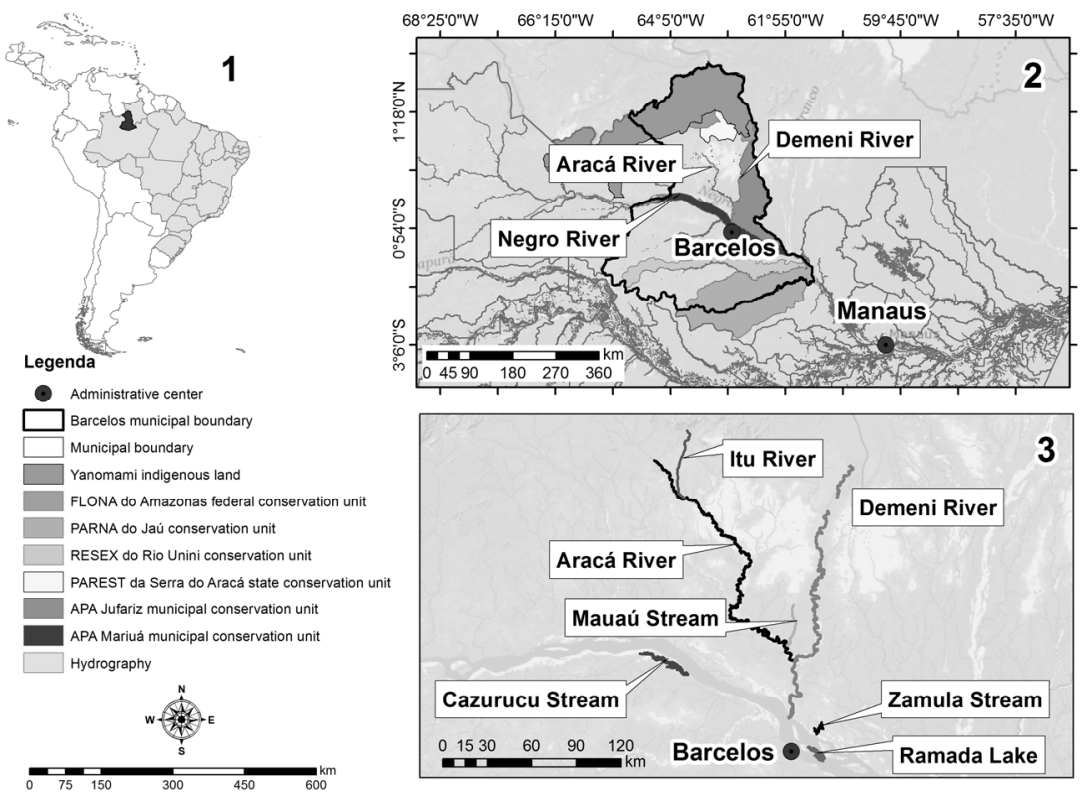

Figure 1: Maps showing the study area: 1) Map of South America showing Brazil, the state of Amazonas and the municipality of Barcelos; 2) Municipality of Barcelos, showing the Negro, Aracá and Demeni Rivers and Conservation Units; 3) Main fishing areas used by commercial fishermen in Barcelos.

\subsection{Data collection}

Data were collected with the aid of a structured questionnaire answered by stall owners and the person responsible for each boat between February 2012 and January 2013. The data for the fishing boats was collected at weekends while the data for stalls was collected during the week.

The information gathered included the fishing area, number of crew, date of departure and arrival, number of hours spent fishing, species caught, fishing devices used, total catch $(\mathrm{kg})$ and price of first sale.

\subsection{Data analysis}

The data were kept in a spreadsheet and analyzed using descriptive statistics to calculate the frequency of occurrence and determine the measures of central tendency and dispersion of the data.

Monthly data on the water level in the Negro River (at the Barcelos hydrological station) were provided by the National Water Agency (ANA) and used to relate production to the annual hydrological cycle.

Fishing effort was calculated according to [8], which suggests that the best formula for determining fishing effort in the Amazon region is the number of 
fishermen in the crew multiplied by the number of fishing days. Fishing effort and catch per unit effort (CPUE) were calculated separately for fishing boats and small boats with outboard motors.

Fishing patterns in terms of the type of boat used in each period of the hydrological cycle were identified using correspondence analysis and the STATISTICA program.

\section{Results}

\subsection{Fish landings}

Fish production in the study area serves two main markets: Barcelos and, primarily, the municipality of São Gabriel da Cachoeira, where it can be sold more profitably, possibly because of the greater purchasing power of the population.

In all, 167 fishing trips were recorded, with a total production of 56.0 tons $(\mathrm{t})$ and a mean landing of $4.7 \pm 2.2 \mathrm{t} /$ month. The maximum landing was $9.2 \mathrm{t}$ in October (dry season), and the minimum $2.5 \mathrm{t}$ in May (flood season). Fishing boats landed an average of $3.6 \pm 2.2 \mathrm{t} / \mathrm{month}$, while the corresponding figure for small boats with outboard motors was $1.1 \pm 0.7 \mathrm{t} / \mathrm{month}$. The latter made the most landings $(51.5 \%)$, but fishing boats caught the most fish.

The volume landed varied with the hydrological cycle and peaked in February (rising-water period) and September and October (dry period) (Figure 2). There was a sudden, abnormal drop in the volume landed in November because of problems with the factory that supplies ice, which led to a drop in the number of fishing trips.

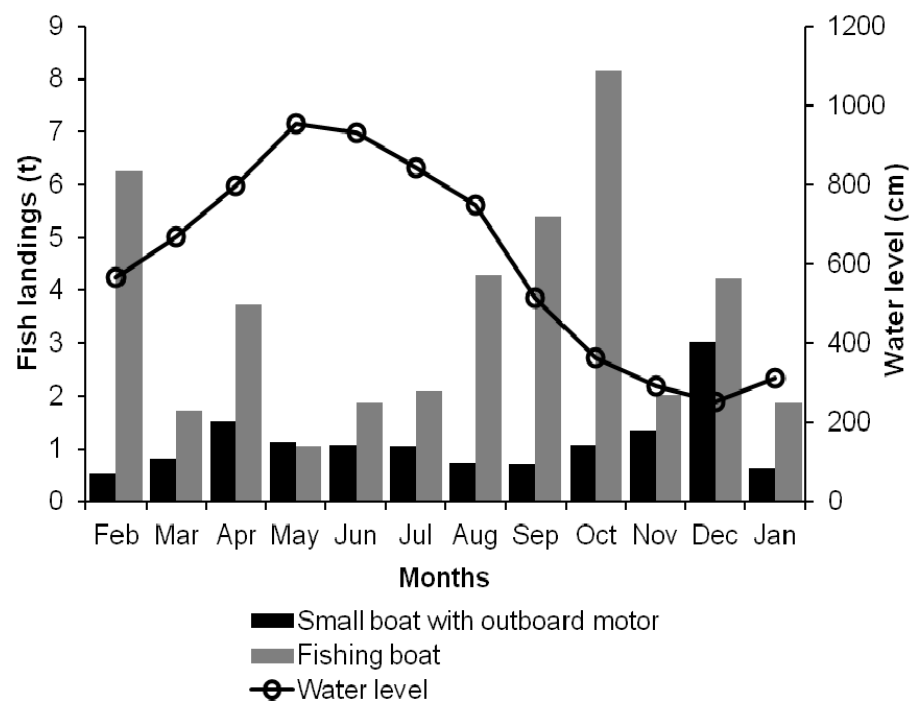

Figure 2: Monthly commercial fish landings in the municipality of Barcelos. 


\subsection{The main species landed}

Twenty-two fish species or groups of species were landed in the municipality by commercial fishermen. Together, the three main species - pacus (subfamily Myleinae) (27.4\%), aracus (family Anastomidae) (11.9\%) and tucunarés (Cichla spp.) - accounted for approximately $50 \%$ of the landing frequency.

The species pacu, aracu, jaraqui and matrinxã are known locally as white fish and have greater commercial value, while other species sold, such as acará, tucunaré, traíra and piranha, are known as black fish and are less valuable.

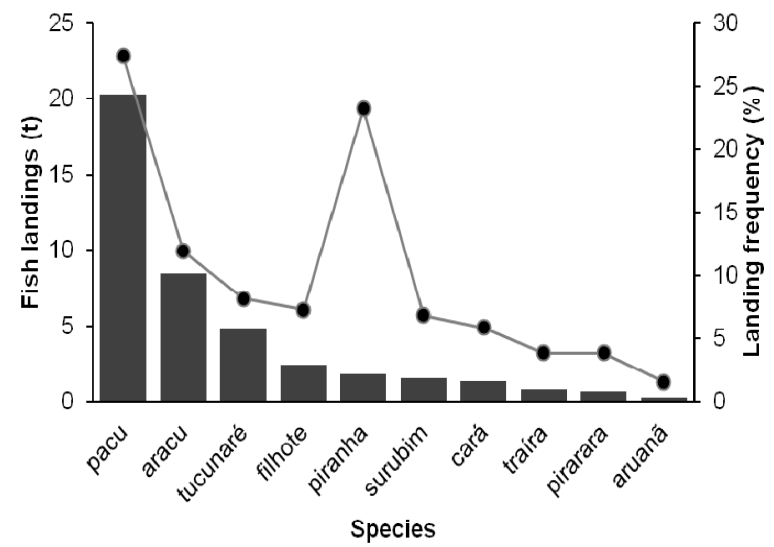

Figure 3: Landing weight and frequency for the main species landed.

Pacu alone was responsible for more than $20.0 \mathrm{t}$ of the total landed. The largest monthly landings were observed when the water level in the river was at its lowest, between September and December, indicating that fish can be more easily caught during this period (Figure 4).

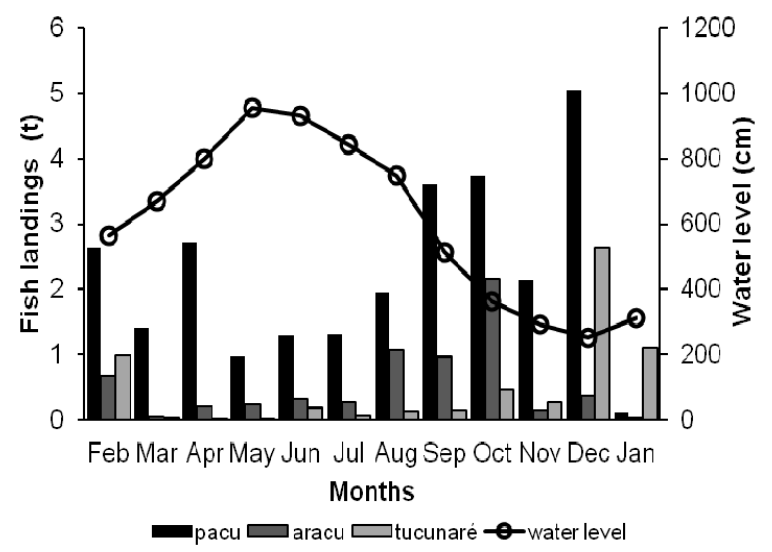

Figure 4: Landings of pacu, aracu and tucunaré in Barcelos. 


\subsection{Fishing areas exploited}

The fishing fleet exploited 68 fishing areas in 39 rivers, 18 lakes and 11 streamlets (11). Of the rivers exploited, the Demeni River had the most fishing trips (24.8\%), followed by the Aracá River (22.3\%) and Itu River (20.7\%). Lakes Anauali (37.3\%), Ramada (31.4\%) and Maxibeda (20.5\%) were the most frequently exploited. The other lakes were exploited sporadically. Zamula (29.4\%), Cazurucu (17.6\%) and Mauaú (14.7\%) were among the most frequently exploited streamlets.

In the correspondence analysis for the fishing boats (Figure 5), dimension 1 (eigenvalue $0.05181 ; 86.89 \%$ inertia) indicated that lakes were exploited during the dry and flood periods whereas the rivers were exploited throughout the hydrological cycle, with slightly more activity during the falling-water period. Streamlets were exploited in all periods except the rising-water period.

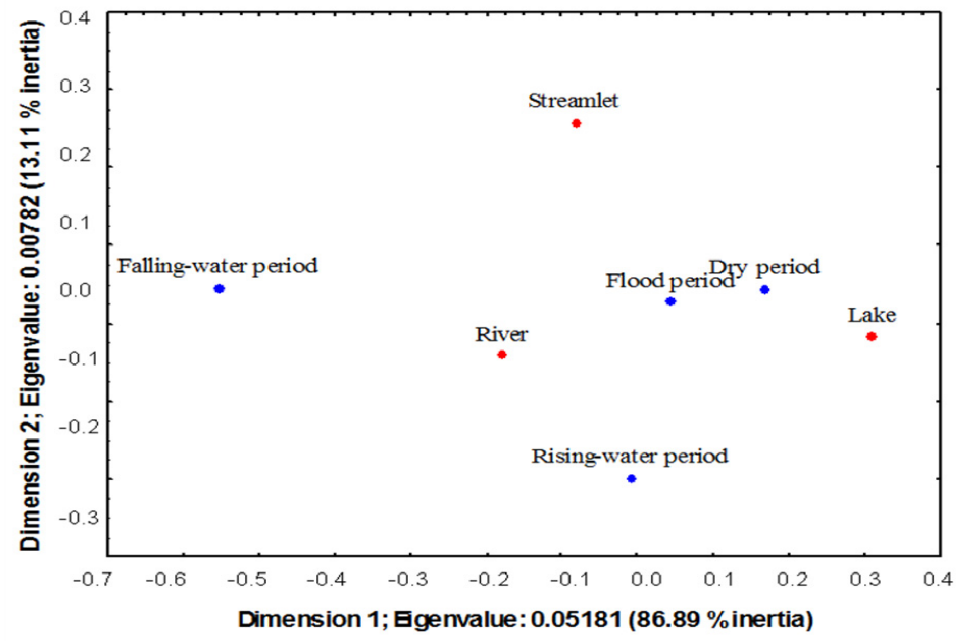

Figure 5: Correspondence analysis for the fishing areas used by fishing boats during the different periods of the hydrological cycle.

In the correspondence analysis with catch data for small boats with outboard motors, dimension 1 (eigenvalue $0.02623 ; 75.13 \%$ inertia) showed that the lakes continued to be the preferred fishing areas in the dry period, while rivers were exploited throughout the year. Streamlets were exploited mainly during the falling-water and flood periods (Figure 6).

\subsection{Fishing effort and catch per unit effort}

Fishing effort for fishing boats was inversely proportional to water level. Hence, the month with the smallest effort, which was coincidentally also the month with the smallest catch, was May, in the flood period (Figure 2). From June onwards, 


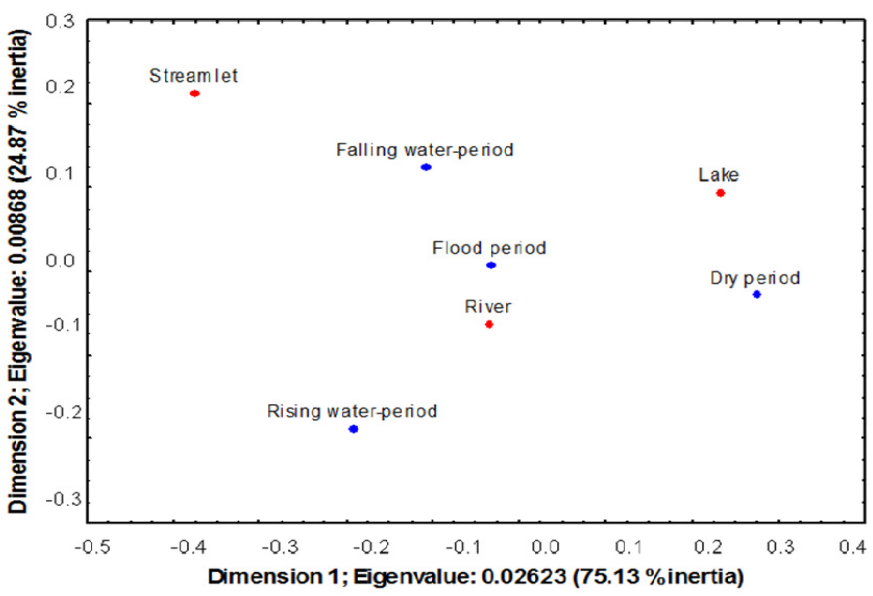

Figure 6: Correspondence analysis for fishing areas used by small boats during the different periods of the hydrological cycle.

fishing effort increased steadily as the water level dropped in the falling-water and dry periods (Figure 7). Fishing effort for small boats with outboard motors followed the same pattern, i.e. a large effort during the dry period, with a peak in December, and a small effort in the flood period, with the lowest value in June (Figure 7).

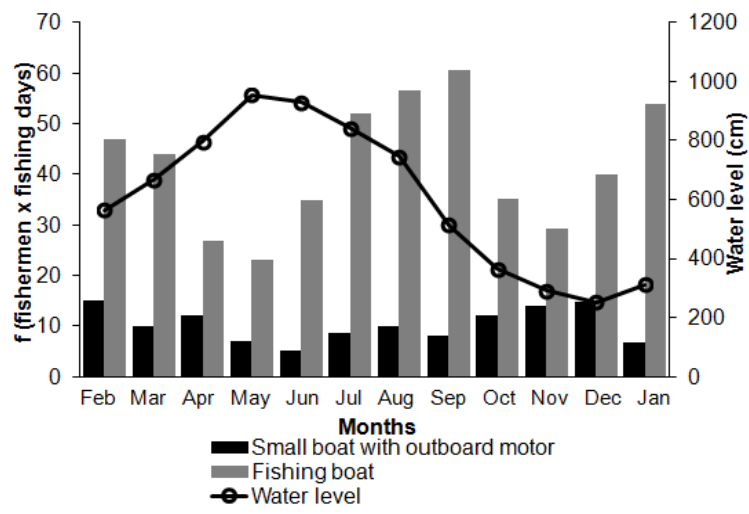

Figure 7: Fishing effort (f) for the Barcelos fishing fleet.

CPUE for fishing boats varied between $8.3 \mathrm{~kg} /$ fisherman/day in May (in the flood period) and $43.3 \mathrm{~kg} /$ fisherman/day in February (in the rising-water period). Mean CPUE was $21.9 \pm 18.3 \mathrm{~kg} /$ fisherman/day. CPUE for small boats with outboard motors was $4.7 \mathrm{~kg}$ /fisherman/day in February (in the rising-water period) and $65.9 \mathrm{~kg} /$ fisherman/day in December (in the dry period). Mean CPUE was $23.9 \pm 18.3 \mathrm{~kg} /$ fisherman/day. 


\section{Discussion}

Other studies in whitewater rivers in the Amazon had already identified a relationship between water level and fish landings $[9,10]$. In these studies the highest landings were observed during low-water periods associated with retraction of the physical environment, when fish are confined to open waters in lakes, making them easier to catch. The reduction in fish landings when water levels are higher and at the beginning of the falling-water period are common characteristics throughout the Amazon [11-13].

According to the interviewees, there are twenty-two species that are most frequently exploited by the fishermen. However, this number may in fact be larger, as several popular names mentioned in the interviews correspond to more than one species. Pacu, aracu and tucunare were the most frequently caught fish in the study, corroborating the findings of [14] and [15] in the same area.

Monthly landing data for pacu showed that production was greater in September, October and December, when water levels are low. The increase in production in April may have been because pacu are often found in large shoals in this period, making it easier to catch them. The greater proportion of pacu and aracu in landings can be attributed to economic factors, which undoubtedly influence the choice of fish caught as both pacu and aracu are among the most prized and widely eaten fish in the region. A further possible factor is the use of gillnets, the main type of net used by the fishermen, as these are suitable for catching fish that migrate in shoals.

Tucunare is one of the main groups of species exploited commercially and among the most important and widely eaten species during the summer, as well as one of the most popular types of fish among the population of the Middle Negro River. It is also one of the favorite species among leisure fishermen in this region [10] as it is attracted by bait and struggles when it is caught.

The importance of the Demeni River for local commercial fishing was readily apparent as this was the main river exploited. According to [14], the Demeni River is one of the most abundant in fish in the region, possibly because it is a whitewater river and therefore more productive than blackwater rivers.

The pattern of river usage during the flood period both by fishing boats and small boats with outboard motors is probably a result of the large number of shoals as it is during this period that various species of Characiformes migrate from the lakes to spawn in the main river channel. As fishing boats cannot enter the lakes during the dry season these vessels are used to store fish, while the small boats are more directly involved in catching the fish. This use of vessels for various purposes in the Solimões-Amazonas channel has already been described in [16].

Fishing effort is reduced during the flood period, unlike in the Madeira River, where fishermen in fishing boats and small boats with outboard motors increase fishing effort during the rising-water and flood periods to make up for the smaller yield during these less productive periods [17]. The reduction in fishing effort for vessels in Barcelos when the water level is higher may be related to dispersion of shoals, making it more difficult to catch the fish. This is because 
when the average water level is high, although fish density is also high, catch efficiency is low and a greater effort is required to maintain yields. Therefore, during the flood period the fishermen reduce the number of trips as catches become smaller and do not cover the costs of the trips. During this period fishermen usually work jointly with a large fishing boat and make weekly or fortnightly trips or do other types of work.

The increase in fishing effort during the falling-water and dry periods may have been because the lower water level and consequent greater fish density make it easier to catch fish. The fishermen are aware of this empirically and therefore make most trips during this period, when they concentrate exclusively on fishing and make daily trips.

The values of CPUE found in this study were lower than those reported in [18] for the Middle Solimões River region (40.0 to $80.0 \mathrm{~kg} /$ fisherman/day) and in [19] for the municipality of Guajará-Mirim $(65.0 \mathrm{~kg} /$ fisherman/day). However, they were similar to the values reported in [17] for Manicore (22.9 and $20.6 \mathrm{~kg} /$ fisherman/day for fishing boats and small boats with outboard motors, respectively) and in [19] for Teotônio (26.6 kg/fisherman/day) and slightly above the values reported in [12] for Santarém (15.0 kg/fisherman/day).

\section{Final considerations}

In view of the preliminary nature of these results, further studies should be carried out to collect more data and generate a time series to corroborate the information presented here. Although preliminary, these data can be used as an initial basis for decisions related to fishery management in this region of the Middle Negro River.

\section{References}

[1] Barthem, R.B. \& Fabré, N.N. Biologia e diversidade dos recursos pesqueiros da Amazônia, pp. 17-62. In: Ruffino, M.L. (Coord.). A pesca e os recursos pesqueiros na Amazônia brasileira. Ibama/Provárzea, Manaus, Brasil, p. 268, 2004.

[2] Batista, V.S. Distribuição, dinâmica da frota e dos recursos pesqueiros na Amazônia Central. 282 f. Tese de Doutorado, Instituto Nacional de Pesquisas da Amazônia/Fundação Universidade Federal do Amazonas, Manaus, Amazonas, 1998.

[3] Silva, A.L. \& Begossi, A. Biodiversity, food consumption and ecological niche dimension: a study case of the riverine populations from the Rio Negro, Amazonia, Brazil. Environment, Development and Sustainability, 11(3), pp. 489-507, 2007.

[4] Sobreiro, T \& Freitas, C.E.C. Conflitos e territorialidade no uso de recursos pesqueiros do Médio Rio Negro. In: Encontro Nacional da ANPPAS, Brasília. Anais. ANPPAS, 1, pp. 78-91, 2008.

[5] Ruffino, M.L. Sistema integrado de estatística pesqueira para a Amazônia. Pan-American Journal of Aquatic Sciences, 3(3), pp. 193-204, 2008. 
[6] Barthem, R.B. \& Goulding, M. Um ecossistema inesperado: a Amazônia revelada pela pesca. Amazon Conservation Association (ACA), Sociedade Civil Mamirauá, Belém, p. 241, 2007.

[7] Chao, N.L.; Petry, P.; Prang, G.; Sonneschien, L. \& Tlusty, M. Conservation and Management of Ornamental Fish Resources of the Rio Negro Basin, Amazonia, Brazil - Project Piaba. $1^{\mathrm{a}}$ ed. Manaus: Editora da Universidade Federal do Amazonas - EDUA, p. 310, 2001.

[8] Petrere, M. Pesca e esforço de pesca no Estado do Amazonas. I. Esforço e captura por unidade de esforço. Acta Amazonica, 8(3), pp. 439-454, 1978.

[9] Batista, V.S. \& Petrere, M. Characterization of the commercial fish production landed at Manaus, Amazonas State, Brazil. Acta Amazonica, 33(1), pp. 53-66, 2003.

[10] Freitas, C.E.C. \& Rivas, A.A.F. A pesca e os recursos pesqueiros na Amazônia Ocidental; Ciência e Cultura (SBPC), Campinas, 58, 2006.

[11] Boischio, A.A.P. Produção pesqueira em Porto Velho, Rondônia (198489) - Alguns aspectos ecológicos das espécies comercialmente relevantes. Acta Amazonica, 22(1), pp. 163-172, 1992.

[12] Isaac, V.J.; Silva, C.O. \& Ruffino, M.L. A pesca no Baixo Amazonas. In: Ruffino, M.L. (Ed.). A pesca e os recursos pesqueiros na Amazônia brasileira. Ibama/ProVárzea. pp. 185-211, 2004.

[13] Doria, C.R.C. \& Lima, M.A.L. A pesca do pacu Mylossoma duriventre (Cuvier, 1818) (Characiformes: Characidae) desembarcado no mercado pesqueiro de Porto Velho - Rondônia. Biotemas, 21, pp. 103-112, 2008.

[14] Silva, A.L. Uso de recursos por populações ribeirinhas no Médio Rio Negro. Tese (Doutorado em Ecologia) - Universidade de São Paulo, São Paulo, 2003.

[15] Barra, C.S.; Dias, C.J. \& Carvalheiro, K. (Orgs.). Como cuidar para o peixe não acabar. São Paulo: Instituto Socioambiental - ISA, (Série Pescarias no Rio Negro), p. 70, 2010.

[16] Batista, V.S.; Chaves, M.P.S.R.; Faria-Júnior; C.H.; Oliveira, M.F.G.; Silva, A.J.I. \& Bandeira, C.F. Caracterização socioeconômica da atividade pesqueira e da estrutura de comercialização do pescado na calha do Solimões-Amazonas. In: O setor pesqueiro na Amazônia: análise da situação atual e tendências do desenvolvimento da indústria da pesca. Manaus: Ibama/ProVárzea, pp. 19-57, 2007.

[17] Cardoso, R.S. \& Freitas, C.E.C. Desembarque e esforço de pesca da frota pesqueira comercial de Manicoré (Médio rio Madeira), Brasil. Acta Amazonica, 37(4), pp. 605-612, 2007.

[18] Viana, J.P. A pesca no Médio Solimões. In: Ruffino, M.L. (Coord.). A pesca e os recursos pesqueiros na Amazônia brasileira. Ibama/ProVárzea, pp. 245-268, 2004.

[19] Doria, C.R.C.; Ruffino, M.L. \& Hijazi, N.C. A pesca comercial na bacia do rio Madeira no Estado de Rondônia, Amazônia. Acta Amazonica, 42(1), pp. 29-40, 2012. 